\title{
Contagious Humanism in Early Nineteenth-Century German-Language Press
}

\author{
HEIDI HAKKARAINEN
}

\begin{abstract}
This article explores the ways the emerging concept of humanism was circulated and defined in early nineteenth-century German-language press. By analyzing a digitized corpus of German-language newspapers and periodicals published between 1808 and 1850, this article looks into the ways the concept of humanism was employed in book reviews, news, political reports, and feuilleton texts. Newspapers and periodicals had a significant role in transmitting the concept of humanism from educational debates into general political language in the 1840s. Furthermore, in an era of growing social problems and political unrest, humanism became increasingly associated with moral sentiments. Accordingly, this article suggests that its new political meanings and emotional underpinnings made humanism culturally contagious, particularly immediately before and during the 1848/49 revolutions.
\end{abstract}

\section{KEYWORDS}

conceptual history, education, emotions, humanism, politics, press, 1848/49 revolutions

In the German history of concepts, the era between 1760 and 1840 has been of special interest. The historian Reinhart Koselleck famously called this period a Sattelzeit, a time when not only cultural formations and social structures but also language underwent significant transformation. Many concepts that would later become an integral part of modern intellectual history were coined in the period following the French Revolution in 1789. One of the key concepts included in the volumes of Geschichtliche Grundbegriffe, which charts the change of politico-social language in German-speaking Europe, was humanism. The concept emerged in the beginning of

This article is part of the project "Viral Culture in Early Nineteenth-Century Europe" (PI Hannu Salmi, Academy of Finland, grant number 327187). I thank the anonymous reviewers for their helpful comments. 
the nineteenth century and was associated with a larger semantic field of human-centered concepts, which acquired emancipatory potential among the rising bourgeoisie. For their part, these enlightened citizens emphasized the role of education in the cultivation of human potential and the individual's relation to the state. ${ }^{1}$

Early nineteenth-century interpretations of humanity, humankind, and humanism followed a long, multifaceted tradition of humanist thought in Europe. ${ }^{2}$ All the major phases of this tradition-Renaissance humanism, neohumanism around 1800, and the "third humanism" in the twentieth century-involved debates about the meaning of and values associated with humanism, which helps explain why the different aspects of different "humanisms" have been approached from different theoretical vantage points within many disciplines. ${ }^{3}$

Yet, extant research has identified the early 1800 s as the period most significant for modern understandings of humanism, because the word and concept of humanism were born then. Although concepts such as humanitas and studia humanitatis date back to antiquity, the concept of humanism $(\mathrm{Hu}$ manismus) was coined by Friedrich Immanuel Niethammer (1766-1848) in 1808. The new German concept was originally used in debates on education, especially in the Gymnasium. The debate between humanist and philanthropist (realist) pedagogues concerned the educational reforms undertaken by German states in the early nineteenth century and was especially focused on the reforms in Bavaria, which preceded those implemented in Prussia

1. Hans Erich Bödeker, "Menschheit, Humanismus, Humanität" [Humankind, humanism, humanity], in Geschichtliche Grundbegriffe: Historisches Lexikon zur politischsozialen Sprache in Deutschland, ed. Otto Brunner, Werner Conze, and Reinhart Koselleck (Stuttgart: Klett-Cotta, 1982), 3:1063-1128. Reinhart Koselleck's notion of Sattelzeit has been recently critically discussed by Helge Jordheim, "Europe at Different Speeds: Asynchronicities and Multiple Times in European Conceptual History," in Conceptual History in the European Space, ed. Willibald Steinmetz, Michael Freeden, and Javier Fernández-Sebastián (New York: Berghahn Books, 2017), 47-62.

2. See Mihai-D. Grigore, "Humanism and Its Humanitas: The Transition from the $H u$ manitas Christiana to Humanitas Politica in the Political Writings of Erasmus," in Humanity: A History of European Concepts in Practice from the Sixteenth Century to the Present, ed. Fabian Klose and Mirjam Thulin (Göttingen: Vandenhoeck \& Ruprecht, 2016), 73-90.

3. On the temporal division of different humanisms, see "Humanismus, Humanität" [Humanism, humanity], in Historisches Wörterbuch der Philosophie, ed. Joachim Ritter (Basel: Verlag Schwabe \& Co, 1974), 3:1218-1231. On the multifaceted history of $h u$ manism, see Hubert Cancic, "Humanismus," in Humanismus: Grundbegriffe, ed. Hubert Cancik, Horst Groschopp, and Frieder Otto Wolf (Berlin: De Gruyter, 2016), 9-16. On the relation between humanist tradition and posthumanism, see Alexander Mathäs, $B e$ yond Posthumanism: The German Humanist Tradition and the Future of the Humanities (New York: Berghahn Books, 2020), 1-36. 
between 1809 and $1819 .{ }^{4}$ However, alongside its place in the pedagogical debates, the concept of humanism began spreading more widely in the 1830s and 1840s. It acquired more radical meanings and was interpreted as implying a range of social attitudes and positions by writers like Arnold Ruge (1802-1880), who briefly worked with Karl Marx in Paris. ${ }^{5}$ In line with this, mass publications like newspapers also came to attribute new meanings to the concept of humanism in the run up to the $1848 / 49$ revolutions.

By focusing on the press, whose role has been understudied in the extant research on the history of humanism, this article aims at broadening our understanding of the changes undergone by the discourse on humanism in early nineteenth-century German-speaking Europe by including references to the concept's use in mass-media publications. ${ }^{6}$ This article draws on Peter de Bolla's work on the discursive practices and networks in which concepts are formed. Instead of tracing the history of a specific concept from one individual thinker to another, de Bolla suggests that historians of concepts focus on the architecture of concepts, or the internal relationships between different concepts. Because concepts both reflect and guide mental patterns, their study offers valuable insights into the ways ideas are formed and transformed in the use of language over time. De Bolla concludes that conceptual history should, rather than concentrating on human agents, dedicate more energy to reconstructing the practices and networks that precondition and shape concepts as cultural entities. ${ }^{7}$

This article argues that the press did more than circulate the new emerging concept of humanism in the fragmented German states and Germanspeaking parts of the Habsburg Empire in the first half of the nineteenth century. More significantly, newspapers and periodicals played an important role in transforming humanism from a pedagogical concept into a political concept in the 1840s. Furthermore, the shifting meanings attributed to $h u$ manism in the press between 1808 and 1850-from the Vormärz era to the age of post-1848 neoabsolutism-shed light on processes of cultural transfer

4. See further Georg Bollenbeck, Bildung und Kultur: Glanz und Elend eines deutschen Deutungsmusters [Education and culture: Splendor and misery of a German model of interpretation] (Frankfurt am Main: Insel, 1994), 142-155.

5. See Bödeker, "Menschheit, Humanismus, Humanität," 1123-1126.

6. See Willibald Steinmetz and Michael Freeden, "Introduction. Conceptual History: Challenges, Conundrums, Complexities," in Conceptual History in the European Space, ed. Willibald Steinmetz, Michael Freeden, and Javier Fernández-Sebastián (New York: Berghahn Books, 2017), 31.

7. Peter de Bolla, The Architecture of Concepts: The Historical Formation of Human Rights (New York: Fordham University Press, 2013), 1-5. However, the reception of the newspapers and periodicals is not included in this study and left for further research. 
in which concepts and ideas not only travel from one place to another but also evolve in time according to historical context. ${ }^{8}$

Previous discussions on the conceptual history of humanism in the nineteenth century have mostly dealt with theoretical pamphlets and the writings of educational theorists, but have overlooked the role of periodicals and newspapers as a site of public debate. ${ }^{9}$ According to Manfred Landfester, only periodicals with a special interest in educational matters were discussing humanism in the early nineteenth century, and only after the middle of the century did the press begin to play a major role in shaping public opinion on the role of humanist education. ${ }^{10}$ However, recently digitized press material makes it possible to take a more detailed look at publications before 1850 and reveal a more nuanced picture of the various meanings ascribed to $h u$ manism in public discussion within the states of the German Confederation. Whereas educational periodicals and literary journals made their mark on the concept's history by reviewing books on humanism and circulating their ideas to a public in the first decades of the century, in the 1840s, humanism began to appear in the daily press more widely: the concept was employed when reporting on issues like the great fire of Hamburg, poverty, social unrest, and political upheavals around 1848.

The source material of this study is the digital corpus Austrian Newspapers Online (ANNO), provided by the Austrian National Library. The digital ANNO collection is part of the Europeana Newspapers network; it contains approximately twenty million pages of German-language newspapers and periodicals with full-text searchability. In addition, the digital repository digiPress: Das Zeitungsportal der Bayerischen Staatsbibliothek was consulted for material that is missing from the ANNO database.

\section{An Expanding Network of Texts}

In 1808, several newspapers and periodicals promoted Friedrich Immanuel Niethammer's book Der Streit des Philanthropinismus und Humanismus in

8. On cultural transfer, see Jörg Rogge and Hannu Salmi, "Memory Boxes: An Experimental Approach to Cultural Transfer in History, 1500-2000," in Memory Boxes: An Experimental Approach to Cultural Transfer in History, 1500-2000, ed. Heta Aali, AnnaLeena Perämäki, and Cathleen Sarti (Bielefeld: transcript, 2014), 11-20.

9. On German humanism as an educational movement, see Manfred Landfester, $H u$ manismus und Gesellschaft im 19. Jahrhundert [Humanism and society in the 19th century] (Darmstadt: Wissenschaftliche Buchgesellschaft, 1988) and Bos van Bommel, Classical Humanism and the Challenge of Modernity: Debates on Classical Education in 19th-Century Germany (Berlin: De Gruyter, 2015).

10. Landfester, Humanismus und Gesellschaft, 14-19. 
der Theorie des Erziehungs-Unterrichts unsrer Zeit by publishing articles and advertisements. ${ }^{11}$ After teaching as Professor of Philosophy at the University of Jena, Niethammer was, in 1807, appointed Central Commissioner of Education to reorganize Bavaria's education system, ${ }^{12}$ a task that was in many ways similar to Wilhelm von Humboldt's job in Prussia. ${ }^{13}$ While working on this significant task, Niethammer wrote his well-known book Der Streit (1808), which for the first time introduced the concept of humanism to a German-speaking readership. In his book, Niethammer emphasized the need to combine older pedagogy-or Humanismus, which was based on the study of classical languages and aimed above all at fostering the humanity of the pupil-with the modern, more practically oriented system of human education, Philanthropinismus. ${ }^{14}$

In the first years after the book's publication, the press primarily used the word Humanismus when referring to Niethammer's ideas; thus, between 1808 and 1815, it was mentioned only thirteen times in the ANNO source corpus. ${ }^{15}$ Book reviews and articles actively commented on Niethammer's views and interpreted them for the reading public. ${ }^{16}$

However, after 1829, public discourse on the concept began to be shaped by new publications, such as F. W. Klumpp's Die gelehrten Schulen nach den Grundsätzen des wahren Humanismus und den Anforderungen der

11. E.g. Friedrich Frommann, "Anzeige für Eltern, Schulvorsteher, Schul- und Privatlehrer" [Ad for parents, school directors, schoolteachers and private teachers], Allgemeine Zeitung, 29 April 1808; "Neue deutsche Bücher" [New German books], Intelligenz-Blatt zum Morgenblatt für gebildete Stände, Nr. 27 1808; “B. R. Z., München, den 30. Sept.,” Augsburger Postzeitung, 3 October 1808.

12. See Gunter Wenz, “F. I. Niethammer (1766-1848)," in Friedrich Immanuel Niethammer 1766-1848: Beiträge zur Biographie und Werkgeschichte [Contributions to the biography and work], ed. Gunter Wenz (Munich: Bayerische Akademie der Wissenschaften, 2009), 1-14, here 3-4.

13. See further Markus Schauer, "Friedrich Immanuel Niethammer und der bildungspolitische Streit des Philanthropinismus und Humanismus um 1800" [Friedrich Immanuel Niethammer and the educational policy dispute of philanthropinism and humanism around 1800], Pegasus-Onlinezeitschrift 5, no. 1 (2005): 28-45, http://www.pegasus-on linezeitschrift.de/erga_1_2005_schauer.html.

14. Friedrich Immanuel Niethammer, Der Streit des Philanthropinismus und Humanismus in der Theorie des Erziehungs-Unterrichts unsrer Zeit, dargestellt von Friedrich Immanuel Niethammer [The dispute of philanthropinism and humanism in the theory of educational schooling of our time] (Jena: F. Frommann, 1808), 14.

15. Most of the references (9) were from Morgenblatt für gebildete Stände and the other (4) from Heidelbergische Jahrbücher für Literatur. In digiPress more references especially from Bavaria are available.

16. E.g. "Der Streit des Philanthropinismus und Humanismus" [The controversy of philanthopinism and humanism], Morgenblatt für gebildete Stände, 24 September 1808. "Jena: Bey Frommann," Göttingische gelehrte Anzeigen, 30 July 1808. 
Zeit. ${ }^{17}$ Some researchers have suggested that because Humanismus was first coined as a polemical concept to advocate classical learning in an era of schooling reforms, it was not as widely used as the concept of Humanität, a notion that was influenced by Johann Gottfried Herder (1744-1803) and frequently appeared in early nineteenth-century intellectual discussions, intertwined with key concepts like Kultur and Bildung. ${ }^{18}$ However, as Bos van Bommel has written in his recent study, Klumpp's book popularized the concept of Humanismus in German-speaking Europe. ${ }^{19}$ By mid-century, it became a widely recognized term, yet one that had multiple meanings.

According to the full-text search engine of the ANNO portal in 2019, the word Humanismus was mentioned 326 times in the press between 1808 and 1850 ; in the digiPress Bayern database, the result was 341 in the same year. ${ }^{20}$ The references overlap to a great extent. Because the references to humanism were relatively few, it was possible to both map the network of texts discussing humanism in the 1830s and 1840s (figure 1) and qualitatively analyze the material. In some texts, humanism appeared only once in passing, while in others it was mentioned several times and discussed explicitly. These texts were selected for close reading.

The results reflect only the features of the source corpus provided by the Austrian National Library, and the findings cannot be generalized to encompass all of the German-language press. However, even though the source corpus is geographically biased and lacks many early nineteenth-century newspapers and periodicals, especially from northern and western parts of German states, such as the Berlin-based Vossische Zeitung, this data gives some indication of the flows and transfer of ideas across political and geographical borders. ${ }^{21}$ Rather than simply providing evidence for an analysis of

17. F. W. Klumpp, Die gelehrten Schulen nach den Grundsaitzen des wahren Humanismus und den Anforderungen der Zeit [The gymnasien according to the principles of true humanism and the demands of the time] (Stuttgart: Johann Friedrich Steinkopf, 1830). See also "Humanismus: Eine vorläufige Schrift" [Humanism: A preliminary script], Blätter für literarische Unterhaltung, 26 August 1829.

18. Bödeker, "Menschheit, Humanismus, Humanität," 1090-1093. See also Cancic, "Humanismus," 12.

19. Bommel, Classical Humanism, 25.

20. By comparison, between the years 1795 and 1850 the word Humanität (humanity) appeared in the ANNO corpus material 8,103 times according to a full text search made in 2019. Because the old German Fraktur typeface is challenging for optical character recognition (OCR), the results are not entirely reliable, changing also constantly in accordance with the ongoing digitization project, but they give some indication of the scale in which these words were circulated in the press.

21. See Matt Erling and Lynne Tatlock, "Introduction: 'Distant Reading' and the Historiography of Nineteenth-Century German Literature," in Distant Readings: Topologies 

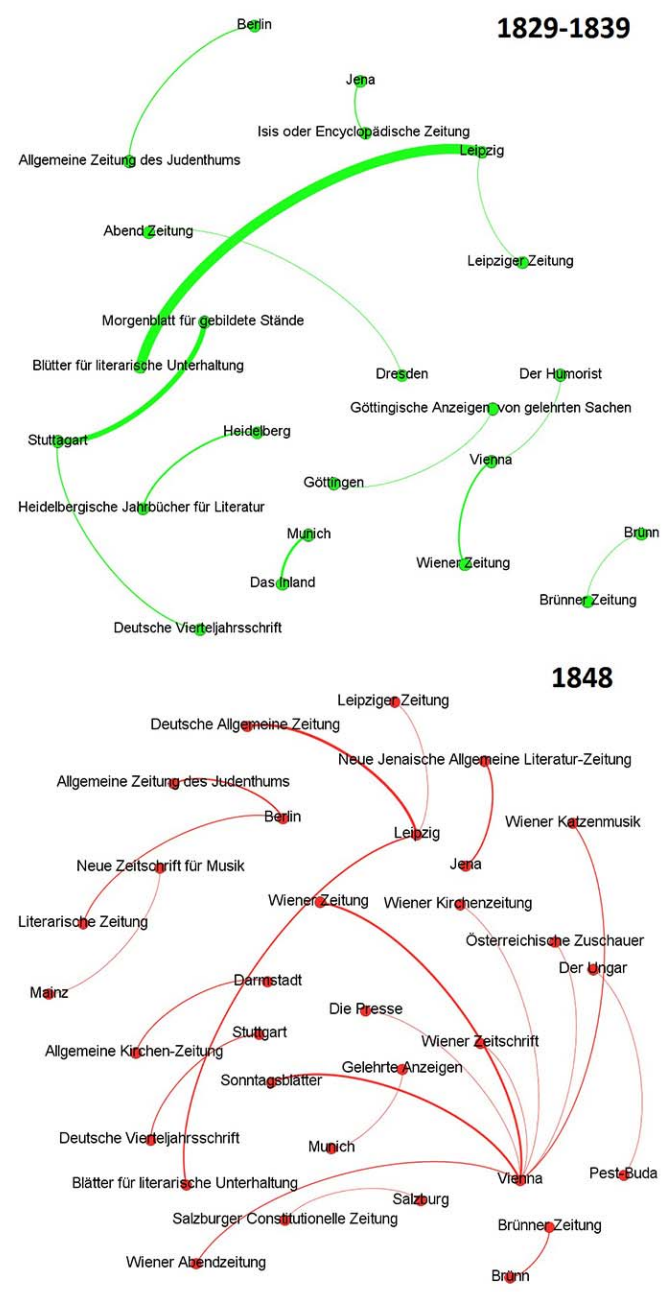

1840-1847

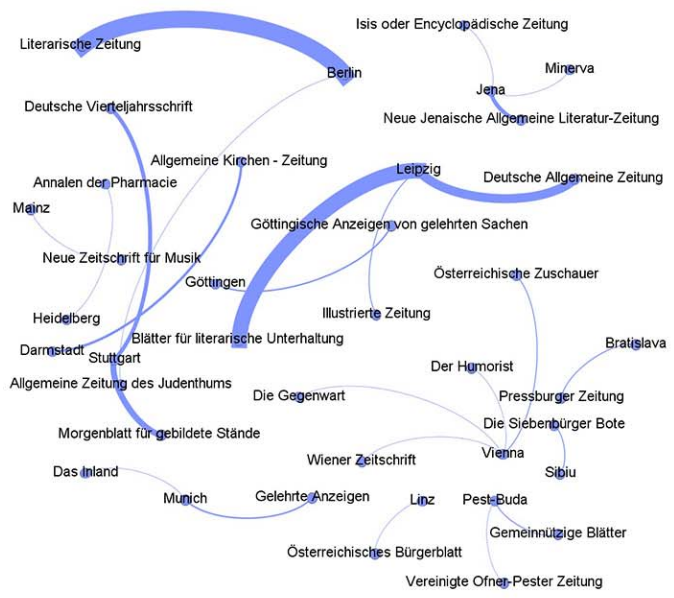

1849-1850

Illustrierte Zeitung

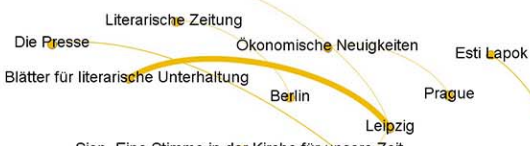

Sion. Eine Stimme in der Kirche für unsere Zeit Österreichische Zuschauer Wiener Zeitung
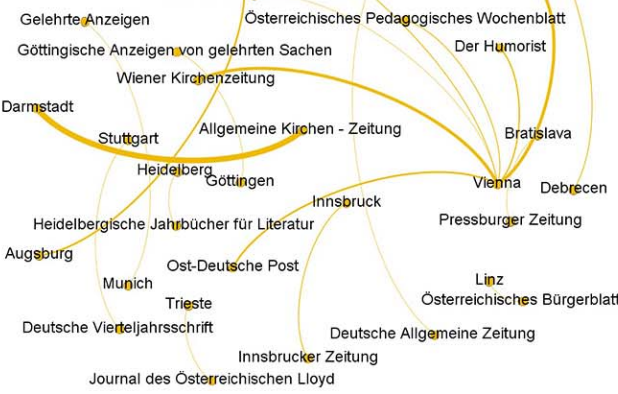

Figure 1. Publications and places of publication 1829-1850.

discourse within the German Confederation (Deutscher Bund 1815-1866), the network of texts discussing humanism highlights the exchange of ideas between German states in the areas of present-day Germany and Austria.

The growth of the number of newspapers by mid-century shaped the discussion on humanism, as did censorship. The states of the German Confederation had their own practices of overseeing and controlling the press. Whereas Prussia and Austria had strong censorship, the states of Bavaria,

of German Culture in the Long Nineteenth Century, ed. Matt Erling and Lynne Tatlock (New York: Camden House, 2014), 1-25. 
Baden, and Württemberg were known for their more liberal attitudes toward the press. The Vormärz era was marked by an effort to create a uniform censorship system for all German states. The Carlsbad Decrees in 1819, initiated by Austria and Prussia, led to a federal press law (Bundespressegesetz) that regulated the press within all the states of the German Confederation between 1819 and $1848 .{ }^{22}$ Censorship was increasingly criticized, and it was abolished in $1848-49 .{ }^{23}$ After the revolutions, the era of neoabsolutism restored censorship.

\section{From the Pedagogical to the Political}

The expanding prominence of the concept of humanism was impacted both by the growth of the press in the 1830s and 1840s and by contemporary education policies and debates. The early nineteenth century was an era of educational reforms as the state gradually became the principal authority organizing educational institutions, even though the Church still had major influence over schooling. ${ }^{24}$ Yet, the transition toward a secularized state-controlled school system occurred within the German Confederation at a different pace: in Austria, for example, educational reforms only began after $1849 .{ }^{25}$

Humanism and philanthropism thus emerged during a period of the secularization of education, and they both offered different approaches as to how the educational system should be set up. As Georg Bollenbeck has argued, humanism and philanthropism were both strongly influenced by the political situation and intellectual culture following the French Revolution. But while philanthropism was associated with the French Enlightenment and Rousseau, humanism was linked to the contemporary intellectual movements of German idealism and romanticism. ${ }^{26}$ In addition, advocates of early nineteenth-century humanism, such as Wilhelm von Humboldt and Friedrich August Wolf, were more interested in Greek culture than Roman cul-

22. Rudolf Stöber, Deutsche Pressegeschichte: Von den Anfängen bis zur Gegenwart [History of the German press: From the beginning to the present], 3rd rev. ed. (Cologne: Herbert von Halem Verlag, 2014), 141-42; Konrad Dussel, Deutsche Tagespresse im 19. und 20. Jahrhundert [German press in the 19th and 20th centuries] (Münster: Lit, 2011), 27.

23. See Pieter M. Judson, The Habsburg Empire: A New History (Cambridge: The Belknap Press of Harvard University Press, 2016), 185-186; Hartmut Pogge von Strandmann, “1848-1849: A European Revolution?," in The Revolutions in Europe 1848-1849: From Reform to Reaction, ed. R. J. W. Evans and Hartmut Pogge von Strandmann (Oxford: Oxford University Press, 2000), 1-8, here 3.

24. Harry Morgan, The Imagination of Early Childhood Education (Westport, CT: Bergin \& Garvey, 1999), 21-26.

25. Landfester, Humanismus und Gesellschaft, 8, 13.

26. See Bollenbeck, Bildung und Kultur, 145. 
ture. Their interpretations of humanism combined historical contemplation with the modern values of freedom, equality, and individuality. Because of this novel interpretation of humanism, the early nineteenth-century movement later came to be called neohumanism. ${ }^{27}$

Following the rhetoric employed in the educational treatises that popularized the concept in the first place, journalistic practices and discursive tactics framed their interpretations of humanism through various dichotomies. Whether pro or contra, the articles approached humanism by contrasting it with realism. The division between humanism and realism was often described in terms of "personal cultivation" versus "useful knowledge," "ideal" versus "empirical," "abstract" versus "practical," and "ancient" versus "modern," and it also indirectly constructed contrasts between the humanities and the sciences. ${ }^{28}$

Because humanism was associated with classical philology-that is, the study of Latin, Greek, and Hebrew-its meaning and usefulness for contemporary society were both questioned and defended in writings on education. ${ }^{29}$ Press coverage included writings for and against humanist education, while writers tried to find a resolution to the seemingly irresolvable conflict. The philanthropist educational ideal of the Enlightenment, which promoted "useful knowledge" and the humanist notion of Bildung as a form of selfrealization, self-understanding, and personal freedom were presented as thesis and antithesis that should be brought together in a synthesis. ${ }^{30}$ Part of the

27. The term "neohumanism" was coined by Friedrich Paulsen in 1885. See further Bommel, Classical Humanism, 3-4.

28. "Die Erziehungs-Systeme der Humanisten und Realisten und ihre Abwege" [The education systems of humanism and realism and their deviations], Das Inland, Tagblatt für das öffentliche Leben in Deutschland, mit vorzüglicher Rücksicht auf Bayern, 8-9 April 1830; "Schriften über der Reform der Universitäten" [Writings on university reform], Morgenblatt für gebildete Stände, 22 January 1838; J. L., "Der Zustand der Chemie in Preussen" [The state of chemisty in Prussia], Annalen der Pharmacie 2 (1840); Karl Hoffmeister, "Berücksichtigung der Individualität bei Unterricht und Erziehung" [Consideration of individuality in teaching and education], Deutsche Vierteljahrschrift 2 (1841); Ph. H. Külb., "Länderkunde: Mittheilungen aus dem Reisetagebuche eines deutschen Naturforschers, England" [Geography: Information from the travel diary of a German natural scientist, England], Neue Jenaische Allgemeine Literatur-Zeitung, 19 June 1843; Mgdb Wschbl.,"Humanismus und Realismus, nicht Humanismus oder Realismus" [Humanism and realism, not humanism or realism], Gemeinnützige Blätter zur vereinigten Ofner und Pester Zeitung, 4 and 6 April 1844; Ein Realschulmann, "Die deutsche Realschule" [German secondary school], Deutsche Vierteljahrschrift 2 (1848).

29. See Friedrich Wilhelm Thiersch, Ueber Gelehrte Schulen mit besonderer Rücksicht aufBayern [On gymnasien with special regard to Bavaria], (Stuttgart und Tübingen: Cotta’sche Buchhandlung, 1829), 3:268-271; Klumpp, Die gelehrten Schulen, 2:ix-x, 14, 274.

30. "Schulwesen” [School system], Morgenblatt für gebildete Stände, 13 October 1834. See Bollenbeck, Bildung und Kultur, 145, 148-155. 
concept of humanism's gradual entry into the mainstream was its being taken up in new cultural domains in the press. A case of republication from the year 1833 illustrates this well. In July 1833, the Blätter für literarische Unterhaltung published an article titled "Women's Riot in the Reformed Church" on a Protestant pastor's sermon in Breslau (Wroclaw) about the responsibilities of the fairer sex to their family and fatherland. The female audience, the article claims, responded by becoming restless, coughing, making all kinds of noise, and even leaving the room in protest. The author makes fun of these misbehaving women and presents this incident as a warning against non-practical education in general and the education of women in particular:

It cannot be denied that humanism has superseded realism in the education of women, just like in the case of Gymnasien. Yours truly has already come across twenty most sweet little noses that have wrinkled [in a] very unfriendly [way] when hearing the word "kitchen." Singing, reading, and going to the theater makes the sum of engagements of the many so-called educated. Of course, only the greatest evil springs from this wrong direction. ${ }^{31}$

The humorous-satirical tone of the text together with the controversial subject matter made it appealing for reprinting. The practice of republishing material from other papers was very common in early nineteenth-century Europe and the United States, where all kinds of texts were republished, from poems to recipes and jokes. Humor could make a text so popular that it went viral. ${ }^{32}$ The "women's riot" text, which discussed an incident in Silesia, traveled from Leipzig in Saxony to the German-speaking parts of the Habsburg Empire. ${ }^{33}$

In addition to gender, the status of the Jewish population in the newly emerging civil society also surfaced in press discussions on humanism. ${ }^{34}$ The

31. "Es läßt sich nicht leugnen, daß der Humanismus in der weiblichen Bildung den Realismus ebenso verdrängt, wie das in den Gymnasien der Fall gewesen ist. Dem Schreiber dieses sind schon an zwanzig allerliebste Näschen vorgekommen, die sich bei dem Worte Küche sehr unfreundlich rümpften. Singen, Lesen, ins Theater gehen macht die Summe der Beschäftigungen vieler sogenannten Gebildeten aus. Natürlich entspringen aus dieser schiefen Richtung die größten Uebel." "Der Damenaufruhr in der reformirten Kirche” [Women's riot in the Reformed Church], Blätter für literarische Unterhaltung, 21 July 1833. All translations are mine unless stated otherwise.

32. See especially Ryan Cordell, David Smith, and Abby Mullen, “A 'Stunning' Love Letter to Viral Texts," Viral Texts: Mapping Networks of Reprinting in 19th-Century Newspapers and Magazines (2015), http://loveletter.viraltexts.org (accessed 24 October 2017).

33. "Der Damenaufruhr" [The riot], Österreichisches Bürgerblatt für Vestand, Herz und Gute Laune, 9 September 1833; "Ein Wort zur Zeit” [One word at a time], Brünner Zeitung, 1 October 1833.

34. Compare Benjamin Maria Baader, "Rabbinic Study, Self-Improvement, and Philanthropy: Gender and the Refashioning of Jewish Voluntary Associations in Germany, 
Allgemeine Zeitung des Judenthums-a paper dedicated to Jewish interests that began publishing in 1837 and was widely read in German-speaking Europe and beyond-touched upon humanism when writing about the status of Jews in Gymnasien. ${ }^{35}$ In 1839, the Allgemeine Zeitung des Judenthums criticized Friedrich Wilhelm Carovés (1789-1852) view of humanism as a higher principle that promised emancipation from religion, thereby conflating Judaism and Christianity. ${ }^{36}$ The paper not only presented Carové's theory of humanism as utopian and unrealistic, but also interpreted it as a threat to the freedom of religion and the right to practice Judaism. ${ }^{37}$ The status and position of Jews in bourgeois civil society continued to be a matter of discussion in the press. In this context, humanism came to connote the natural equality of all human beings and their equal rights and responsibilities. ${ }^{38}$ References to humanism included attacks on anti-Semitism, ${ }^{39}$ but they also juxtaposed Judaism and humanism..$^{40}$ This tendency to juxtapose humanism with religion became even more apparent in discussions on humanism and Christianity.

Already at the turn of the nineteenth century, the humanists' enthusiasm for ancient Greece had caused suspicion that they had an anti-Christian orientation.${ }^{41}$ Press reviews in the early 1830 s began to touch upon the relationship between humanism and Christianity, which later became a highly controversial issue in the 1840 s and 1850 s. $^{42}$ In 1843 , the debate escalated, especially in the conservative Literarische Zeitung, which published a series of articles written against the Gymnasium and accused humanism's proponents of paganism. ${ }^{43}$ Humanism was maligned as a philosophy that fostered ego-

1750-1870," in Philanthropy, Patronage, and Civil Society: Experiences from Germany, Great Britain, and North America, ed. Thomas Adam (Bloomington: Indiana University Press, 2004), 163-165.

35. "Politik: Zeitungsnachrichten" [Politics: Newspaper news], Allgemeine Zeitung des Judenthums, 28 October 1837.

36. Friedrich Wilhelm Carové, Neorama, 3rd part, Skizzen zur Kultur- und Kunstgeschichte (Leipzig: O. Wigand, 1838).

37. “Neorama von Carové,” Allgemeine Zeitung des Judenthums, 12 March 1839.

38. "Zur Judenfrage" [On the Jewish question], Blätter für literarische Unterhaltung, 1 March 1846: "Herstellung eines allgemeinen Humanismus."

39. -ek., "Die Juden in Prag" [The Jews in Prague], Sonntagsblätter, 3 September 1848.

40. "Zur Frage der Emanzipation der Juden" [On the question of the emancipation of the Jews], Blätter für literarische Unterhaltung, 18 January 1849.

41. Landfester, Humanismus und Gesellschaft, 43-44.

42. See e.g. the anonymous review on the book Reise nach Südafrika und Darstellung meiner während 8 Jahren daselbst als Missionnair [sic] unter den Hotten-totten gemachten Erfahrungen in Blätter für literarische Unterhaltung, 8 March 1831; E. W., "Bey Schuberth und Niemeyer: Drey Schulreden," Göttingische Anzeigen von gelehrten Sachen, 20 July 1833.

43. Bommel, Classical Humanism, 168-169. 
ism (Selbstsucht) and placed the human being, instead of God, at the center of the universe ${ }^{44}$ For its part, this critique reflected a wider anthropocentric turn of the concept of humanism in the $1840 \mathrm{~s} .{ }^{45}$ Consequently, humanism was increasingly seen in the press as an antireligious movement, and it was repeatedly attacked in religious publications. For example, after 1848, the conservative Catholic Wiener Kirchenzeitung repeatedly attacked humanism in its pages and presented it as a radical movement and a threat to social order. ${ }^{46}$ This was related to the fact that in the late 1840 s and especially in the revolutionary years, when Left Hegelians injected the notion of humanism with political content that was debated in the press. ${ }^{47}$

Left Hegelians were one among many movements of 1830s Europe that gained particular popularity among students, whose numbers were growing. ${ }^{48}$ Following Hegel's death in 1831, his students and followers created new interpretations and radical theories characterized by a dramatic postChristian tone. ${ }^{49}$ One of the most influential thinkers of the Young Hegelians, Ludwig Feuerbach, argued that philosophy should be detached from religion. Similarly, Arnold Ruge demanded a separation of religion from philosophy and political life. ${ }^{50}$

In the press, Ludwig Feuerbach, his brother Friedrich Feuerbach, and Arnold Ruge were associated with antireligious humanism. Ruge, who was the editor of the Hallische Jahrbücher (1838-43) and, together with Karl Marx, of the Deutsch-Französische Jahrbücher (1843-44), developed a political interpretation of humanism that became especially popular in the Blätter für literarische Unterhaltung. ${ }^{51}$ At the same time, other publications pitted

44. "Oeffentliche Meinung und politische Institutionen" [Public opinion and political institutions], Literarische Zeitung, 25 March 1843. See also "Zur Verständigung über das Christliche und Philologische der höheren Schule," Literarische Zeitung, 13 May 1843; "Die Gegner des Artikels Ueber das religiös-sittliche Bewusstsein der Philologen," Literarische Zeitung, 27 May 1843.

45. See Bödeker, "Menschheit, Humanismus, Humanität," 1121-1123.

46. See especially the article series by pseudonym K. E., "Das Christenthum und der Humanismus in der Religion und Politik" [Christianity and humanism in religion and politics], Wiener Kirchenzeitung, 27 February and 1, 3 and 6 March 1849.

47. See "Arnold Ruge und der moderne Humanismus," Literarische Zeitung, 6 December 1845 .

48. R. J. W Evans, "Liberalism, Nationalism, and the Coming of the Revolution," in The Revolutions in Europe 1848-1849: From Reform to Reaction, ed. R. J. W. Evans and Hartmut Pogge von Strandmann (Oxford: Oxford University Press, 2000), 9-26, here 15.

49. Warren Breckman, Marx, the Young Hegelians, and the Origins of Radical Social Theory: Dethroning the Self (Cambridge: Cambridge University Press, 1999), 95.

50. Arnold Ruge, Zwei Jahre in Paris: Studien und Erinnerungen [Two years in Paris: Studies and memories], 2nd part (Lepzig: Verlag von Wilhelm Jurany, 1846 ), 7.

51. "Arnold Ruge und sein neuester Standpunkt," Blätter für literarische Unterhaltung, 
humanism and religion against one another as polar opposites. ${ }^{52}$ As it shifted terrain from the world of higher education to that of politics, the concept took on new meanings. Furthermore, humanism became attached to various social debates and issues of human suffering. In this process, humanism more generally signified means of expressing and cultivating humanness and humanity.

\section{Humanism and Menschenliebe}

The semantic field of human-centered concepts was invested with various emotional connotations, such as compassion or Barmherzigkeit, which were seen as constituting an innate part of humanness; these connotations were revitalized in the nineteenth-century understanding of humanism. ${ }^{53}$ In the 1840 s, humanism was associated with not only intellectual categories but also feelings, such as compassion for the poor and unfortunate. The more humanism was used in conjunction with concepts such as Humanität (humanity) and Sittlichkeit (morality), the more it was read as referring to moral sentiments. ${ }^{54}$ At the same time, especially in Great Britain and France, moral philosophy became intimately interlinked with emotions, as the nineteenth-century middle classes understood moral sense as being dependent on the cultivation of appropriate feelings. The capacity to feel compassion was supposed to distinguish the members of the middle-class from other classes and thus showed their virtue. ${ }^{55}$

One text indicative of the emotional turn in understandings of humanism was "Seekönigin als Feuerbraut" (Queen of the sea as bride of fire), an article on the great fire of Hamburg that destroyed large parts of the city in 1842. It was originally published in the Austrian humorous magazine Der Humorist on 18 May $1842,{ }^{56}$ and was republished several times that same year. In Austria, this text appeared five days later in the Österreichisches Bürgerblatt

7 January 1846; “Arnold Ruge,” Blätter für literarische Unterhaltung, 1 and 4 August 1847; "Polemische Briefe von Arnold Ruge," in the series "Offene Briefe zur Vertheidigung des Humanismus," Blätter für literarische Unterhaltung, 11 January 1848.

52. E., "Das Christenthum und der Humanismus in der Religion und Politik," Wiener Kirchenzeitung, 27 February and 6 March 1849.

53. See Bödeker, "Menschheit, Humanismus, Humanität," 1063-1184.

54. E.g. "Ueber Friedrich Hebbel als dramatischer Dichter," Blätter für literarische Unterhaltung, 4 December 1847.

55. Margrit Pernau, "Civility and Barbarism: Emotions as Criteria of Difference," in Emotional Lexicons: Continuity and Change in the Vocabulary of Feeling 1700-2000, ed. Ute Frevert et al. (Oxford: Oxford University Press, 2014), 230-259, here 237-240.

56. M.G. Saphir, “Hamburg: Die Seekönigin als Feuerbraut," Der Humorist, 18 May 1842. 
für Verstand, Herz und gute Laune. ${ }^{57}$ Then the text traveled further to Frankfurt and Augsburg. ${ }^{58}$

The text was written by the well-known satirist Moritz Gottlieb Saphir (1795-1858), who had begun publishing his journal Der Humorist in 1837 in Vienna after various journalistic activities in Berlin and Munich. ${ }^{59}$ However, the article was by no means a humorous piece of writing but a serious outcry (Aufruf an die Menschheit) that appealed to humanity and humanism around the world, from Lisbon to Constantinople, Amsterdam, South America, London, and German lands. ${ }^{60}$ By speaking directly to readers' sense of pity and compassion, the text applied humanism as a term that would unite people in different regions and countries and bring them together to mourn the loss caused by the catastrophe. Humanism was here understood as a means of creating a universal community joined by its love for humanity, or Menschenliebe:

All these manifestations of a so-called "patriotism" shrink together in opposition to the claims that the "humanism" is making and will make to the people! ... There is a big cathedral in the world: it is called: humankind! To build this cathedral leads stone to stone, monument to monument, benevolence to benevolence, love for humanity to love for humanity, until it ascends, the perfect construction of humankind in the divine and Christian sense, up to Heaven to connect it with the purified earth! ${ }^{61}$

Similar to the aforementioned "women's riot" piece, this text had a strong affective charge-this time related to mourning and grief-which probably explains why it was republished by other newspapers. Moreover, it

57. "Hamburg: Die Seekönigin als Feuerbraut,” Österreichisches Bürgerblatt für Verstand, Herz und gute Laune/Die Warte an der Donau, 23 May 1842.

58. "Hamburg: Die Seekönigin als Feuerbraut," Frankfurter Konversationsblatt, 26 May 1842; "Hamburg: Die Seekönigin als Feuerbraut," Der Sammler: Ein Blatt für Unterhaltung und Belehrung 21 /Augsburger Abendzeitung, 1 January 1842.

59. On Saphir, see Jefferson S. Chase, Inciting Laughter: The Development of "Jewish Humor" in 19th-Century German Culture (Berlin: Walter de Gruyter, 2000); Mary Lee Townsend, Forbidden Laughter: Popular Humor and the Limits of Repression in Nineteenth-Century Prussia (Ann Arbor: University of Michigan Press, 1992).

60. M.G. Saphir, “Hamburg: Die Seekönigin als Feuerbraut,” Der Humorist, 18 May 1842.

61. Ibid. "Alle diese Manifestationen eines sogenannten 'Patriotismus' schrumpfen zusammen im Gegenhalte mit den Reklamationen, welche der 'Humanismus' an die Menschen macht, und zu machen hat!. . . Es steht ein großer Dom in der Welt: er heißt: die Menschheit! An diesem Dom baut, da führt Stein auf Stein, Denkmal auf Denkmal, Wohlthätigkeit auf Wohlthätigkeit, Menschenliebe auf Menschenliebe auf, bis er hinaufsteigt, der vollendete Bau der Menschheit im göttlichen und christlichen Sinne bis in den Himmel, um ihn zu verbinden mit der geläuterten Erde!" 
offers insight into the ways concepts represent not merely historical "ways of thinking" but also the role emotions play in the application and interpretation of concepts. ${ }^{62}$

As historian Hannu Salmi has shown, media coverage of catastrophic events, such as fires or natural disasters, was an important part of the early nineteenth-century press, and news about catastrophes sometimes traveled around the globe. ${ }^{63}$ News on catastrophes could also become interlinked with contemporary intellectual ideas and concepts, shaping their meanings and spreading them to a large geographical area. Humanism and the wide range of feelings it connotated, from love and Menschenliebe to pity and compassion, could thus be seen as a proper reaction to and perhaps also as a means of overcoming difficult issues like human suffering, which was gradually becoming a prevalent feature of modern urban life and in texts on it.

Yet, in addition to sentimental benevolence, more radical voices also began employing humanism to criticize social structures that perpetuated human suffering. ${ }^{64}$ For example, a feuilleton article from the Wiener Zeitschrift that dealt with poverty in London in 1846 presented humanism as an insufficient cure for the social diseases that were spreading in Europe: "The humanism of our day is the greatest homeopath: it heals mere symptoms and these only with the smallest doses. There are individual institutions for individual crimes of society, just as there are individual compassionate hearts for the suffering of individuals. However, the world has no heart and no institutions for the great universal sufferings of humankind." ${ }^{65}$ This example of a Viennese publication extrapolating universal consequences from the urban misery in London illustrates how a new transnational awareness followed the vast extension of transportation and communication infrastructures in the 1840s. More texts traveled at a new speed and with a wider readership. ${ }^{66}$

62. See Steinmetz and Freeden, "Introduction," 2.

63. Hannu Salmi, "Catastrophe, Emotions and Guilt: The Great Fire of Turku, 1827," in Catastrophe, Gender and Urban Experience, ed. Deborah Simonton and Hannu Salmi (New York: Routledge, 2017), 121-138.

64. “Die soziale Frage," Blätter für literarische Unterhaltung, 12 February 1846.

65. "Der Humanismus unserer Tage ist der größte Homöopath: er heilt nur Symptome und diese nur mit den kleinsten Dosen. Man findet einzelne Anstalten für einzelne Gebrechen der Gesellschaft, wie man einzelne mitfühlende Herzen findet für leidende Individuen, aber die Welt hat kein Herz und keine Anstalten für die großen allgemeinen Leiden der Menschheit." "Der Doppeltvermählte. Probe aus dem kürzlich erschienenen Buche: 'Mittheilungen aus den Papieren eines Wiener Arztes,'” Wiener Zeitschrift, 15 December 1846.

66. See E. J. Hobsbawm, The Age of Revolution: Europe 1789-1848 (London: Abacus, 1977), 360; Strandmann, “European Revolution," 3. 
However, instead of taking the road of naïve sentimentality, the German-language public debates of the 1840s molded humanism into a political concept to improve society. The new political interpretation of humanism was strongly influenced by Ruge, who advocated universal cosmopolitan solidarity, and Ludwig Feuerbach, who also reinterpreted and popularized the concept of Menschenliebe as part of his radical post-Christian philosophy. ${ }^{67}$

The role of emotions in shaping political movements and social change has been the subject of numerous studies. ${ }^{68}$ Sarah Ahmed has pointed out that love has a particular capacity to mobilize political action in a legitimate and socially acceptable manner. Furthermore, Ahmed describes love as crucial for social bonding. It is a "sticky" emotion that is often used in cultural narratives to help individuals bond and organize themselves into larger collectives that are tied together by identification with an ideal. ${ }^{69}$ In the 1840 s, humanism seemed to provide a new kind of ideal that resonated with other emancipatory contemporary ideas, such as equality, freedom, and brotherhood, which had continued to shape the intellectual landscape of Europe after the French Revolution.

In the 1840s, an era of growing social tensions, including increasing urban poverty, hunger crises and demands for the emancipation of the middle classes, humanism thus emerged as a highly affective concept applied to both proclaim compassion and international solidarity across national borders and to promote emancipation from the old social and political structures. Humanism was imbued with positive meanings: it combined love for humanity with ethics, political action, and a hopeful orientation toward the future. This new interpretation of humanism helps us to understand why it became contagious in the immediate lead-up to and in the run of the German revolutions. The means by which negative emotions related to inadequate and oppressive social and political structures were transformed into positive ones gives insight into the ways emotions are narrated and utilized in political activity. The political connotations and emotional underpinnings that began to accumulate in the press in the 1840s developed further during the revolutions of $1848-49$.

67. Ludwig Feuerbach, Das Wesen des Christentums [The essence of Christianity] (Leipzig: Otto Wigand, 1841), 60.

68. On emotions and the French Revolution, see William M. Reddy, The Navigation of Feeling: A Framework for the History of Emotions (Cambridge: Cambridge University Press, 2001), 139-210.

69. Sarah Ahmed, The Cultural Politics of Emotion (Edinburgh: The Edinburgh University Press, 2014), 122-124. See “Zur Judenfrage," Blätter für literarische Unterhaltung, 1 March 1846: "Bruderliebe ... welche den Menschen mit dem Menschen verknüpfen müsse." 


\section{Contagious Humanism and the 1848-49 Revolutions}

The 1848-49 revolutions in Europe were an uncoordinated wave of revolutions that moved from one country to another in a short period of time. The chain of revolutions and uprisings began to spread across Europe in early 1848. In March, the revolutions moved to German-speaking Europe. The repressive pre-March era ended with an abrupt overthrow of the established political order, which had been designed at the Congress of Vienna in 181415 and ruled over by Chancellor Klemens von Metternich (1773-1859) until $1848 .^{70}$

The most rapid rise in references to humanism in the ANNO source corpus took place during the social and political upheaval of the revolutionary years. As seen in the graphic below, the number of hits for the word Humanismus grew in the 1840s and peaked in the year 1848 (table 1). Apparently, the spread of humanism was a particular phenomenon of the press, because a search in Google Books shows no such peak in German published books from the same period of time. ${ }^{71}$

Table 1. Keyword search for "Humanismus" in the ANNO database.



Source: ÖNB.

70. On the outbreak of the 1848 revolutions, see Jonathan Sperber, The European Revolutions, 1848-1851 (Cambridge: Cambridge University Press, 1994), 105-147.

71. Google Books Ngram viewer: https://books.google.com/ngrams. 
Similar to humanism, an analysis of references to Humanität between the years 1795 and 1850 in the ANNO source corpus reveals that it too peaked during the years of the German revolutions of 1848-49 (table 2).

Table 2. Keyword search for "Humanität" in the ANNO database.

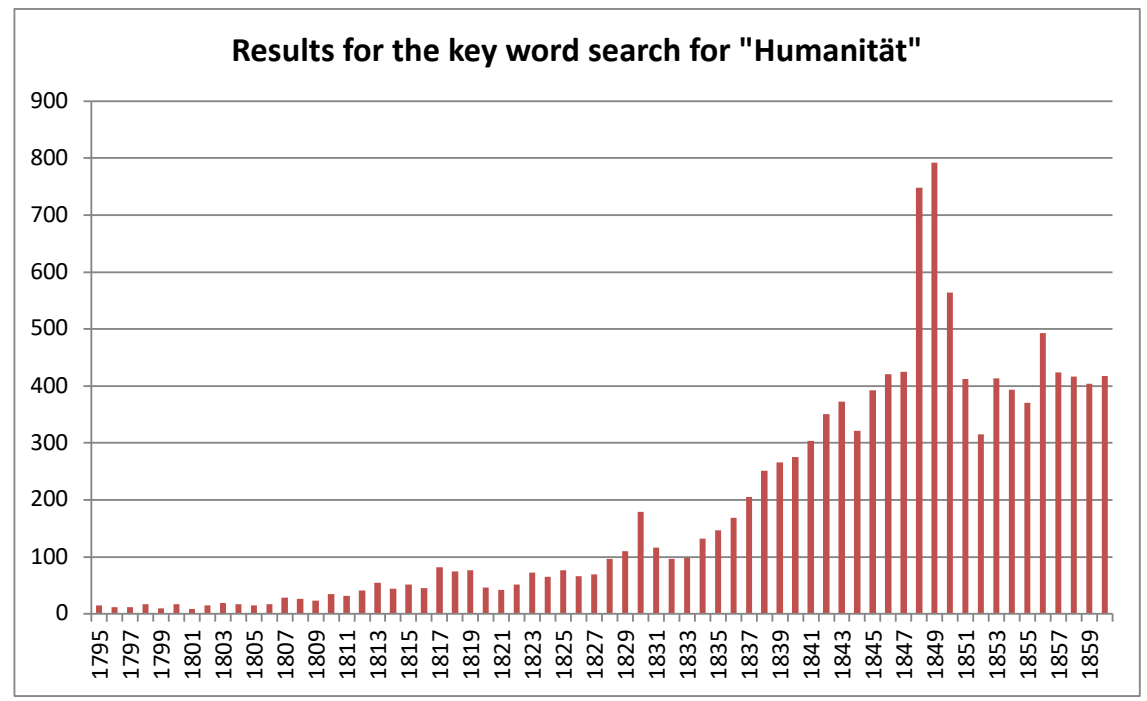

Source: ÖNB.

These diagrams are based on a selection of texts and only reflect the features of the source corpus of the Austrian National Library. In the partly overlapping digiPress corpus, similar trends are visible, but the results are slightly different, which indicates that the uptick in references to humanism in 1848 may have been limited to Austrian material. ${ }^{72}$ Furthermore, it is important to keep in mind that multiple factors might have influenced the high number of hits for the word Humanismus. Niethammer passed away on 1 April 1848 right after the revolution had broken out, and there were several obituaries and other articles on his work in the press. In addition, there were advertisements for the book Die Bewegung des Socialismus, Humanismus und Demokratismus unserer Tage, which was published under a pseudonym in the revolutionary year, ${ }^{73}$ one such advertisement appeared, for instance, in

72. Humanismus: 1840 (19); 1841 (10); 1842 (25); 1843 (8); 1844 (16); 1845 (15); 1846 (24); 1847 (32); 1848 (25); 1849 (16). Humanität: 1840 (441); 1841 (447); 1842 (500); 1843 (430); 1844 (601); 1845 (630); 1846 (720); 1847 (751); 1848 (1210); 1849 (1218). https://digipress.digitale-sammlungen.de/ (accessed 16 April 2019).

73. Benno alias Theobald Bruno Bucher, Bewegung des Socialismus, Humanismus und Demokratismus unserer Tage [Movement of socialism, humanism and democratism of our day] (Bautzen: Weller, 1848). 
the Leipziger Zeitung, the leading newspaper in the eastern parts of German states. ${ }^{74}$ Yet, as the title of the book indicates, the peak in references in the source corpus can also be explained by the nascent political interpretation of humanism, which was used as a mobilizing concept during the uprisings as the press spread information on the revolution from country to country.

Pieter M. Judson, among others, has suggested that new forms of public organization and communication were vital for the outbreak of the revolution in $1848 .{ }^{75}$ The revolution in the German states did not have one, but many centers, nor was it organized by any single party. Rather, it was a wave of uprisings that moved from country to country. The press reported on events from faraway cities and thus joined revolutionaries in producing uncensored publicity. ${ }^{76}$

In 1848, humanism appeared in the press in several ways. The previously discussed political and moral connotations of humanism survived into the revolutionary period and became even more strongly articulated in 1848 . For example, an article on fifteenth-century humanism constructed allegorical parallels between the past and the present, depicting classical humanism as a moral movement that had challenged established power and overthrown old privileges. ${ }^{77}$ On the other hand, a text about poverty utilized humanism as something felt and experienced rather than thought, describing it with phrases like "sympathy for the agony of humankind" and "feelings of brotherhood and human equality." 78 In addition, humanism also appeared in other types of text; for instance, in a political report by the Frankfurt Parliament (Frankfurter Nationalversammlung) that cited Arnold Ruge's use of it as a political and moral principle intended to guide all political decisionmaking-even if that meant legitimizing political violence. ${ }^{79}$ Here, $h u$ manism was presented not as an intellectual category nor as an academic movement, but as a political principle that incorporated into one word multifaceted meanings and emotional implications that had evolved over de-

74. "Literarische Anzeigen," Leipziger Zeitung, 6 April 1848. See also "Bei Weller in Bautzen," Deutsche Allgemeine Zeitung, 31 May 1848; "K. Hof- und Staats-Bibliothek," Gelehrte Anzeigen, 29 June 1849.

75. Pieter M. Judson, Exclusive Revolutionaries: Liberal Politics, Social Experience and National Identity in the Austrian Empire, 1848-1914 (Ann Arbor: University of Michigan Press, 1996), 29-68.

76. See, e.g., “Weltbühne: Berlin,” Der Ungar, 30 March 1848.

77. "Die Anfänge der Prager Universität, mit Bezug auf den Entwicklungsgang der deutschen Universitäten,” Deutsche Vierteljahrsschrift 3 (1848), 78.

78. "Sympathien für die Noth der Menschheit" and "Gefühle der Brüderlichkeit und menschlichen Gleichheit." "Ein Vorschlag gegen das Bettelunwesen,” Wiener Abendzeitung, 26 June 1848.

79. A. Z., "Frankfurt a. M., 27. Juli. Die Einverleibung Polens in den deutschen Bund," Salzburger Constitutionelle Zeitung, 1 August 1848. 
cades in early nineteenth-century texts. Moreover, this example illustrates well the important role played by the press in mediating between spoken words and printed texts, because the newspapers captured contemporary political rhetoric in print. ${ }^{80}$

Thus, the sources analyzed suggest that, especially in 1848, humanism was re-evaluated and adopted as an ism in contemporary political language. Modern isms significantly shaped nineteenth-century politics, as they were used for forming group identities, ideological positions, and intellectual categories. They functioned as mobilizing concepts for political movements, which were often clustered together in public discourses. Recent discussions on the rhetorical use of isms has drawn attention to the fact that isms have also been used to make references to the past and to shape and take possession of intellectual traditions. In addition, isms are often used with a universalizing tone. ${ }^{81}$ Humanism is a prime example of this.

In 1848, in the material provided by the Austrian National Library, humanism began to be discussed in relation to other isms, such as socialism, liberalism, and nationalism, which also spread with the revolutions as the German states sought to unite at the same time as many parts of the Habsburg Empire were fighting for their independence. However, in contrast to nationalism, those who used the term humanism proclaimed ideas of cosmopolitism and international solidarity, which were an important part of the revolutionary public sphere, especially in the optimistic early phase in the spring of $1848 . .^{82}$ In the first months of revolutionary turbulence, references to humanism appeared in the context of discussions on human and social betterment. It drew some of its contagiousness from the (utopian) optimism related to the overthrow of the old system.

One of these optimistic texts was Ferdinand Kürnberger's exultant article declaring the nineteenth century to be the century of freedom. Kürnberger (1821-79) was an Austrian writer who participated in the 1848 revolution and contributed to several issues of the Sonntagsblätter. His article about freedom, published in June 1848, articulated hope for the future, which was typical for early-phase revolutionary publications. According to Kürnberger, the present was the beginning of a new, better era. Freedom was no longer a local or national issue, but had become a worldwide pursuit

80. See also an account of Ruge's lecture in Berlin published in Deutsche Allgemeine Zeitung, 27 August 1848.

81. Jussi Kurunmäki and Jani Marjanen, "Isms, Ideologies and Setting the Agenda for Public Debate," Journal of Political Ideologies 23, no. 3 (2018): 256-282, https://doi.org/ 10.1080/13569317.2018.1502941; Jani Marjanen, "Editorial: Ism Concepts in Science and Politics," Contributions to the History of Concepts 13, no. 1 (2018): v-ix, https://doi.org/ $10.3167 /$ choc.2018.130101.

82. See Strandmann, "European Revolution," 4. 
of humankind. Whereas past freedom had been characterized by nationalism, present and future freedom were characterized by humanism..$^{83}$

In addition, in 1848, humanism appeared in early socialist discourse, where it was associated with the need to emancipate people from outdated economic and social forms and thought patterns that had sustained inequality and social injustice. On 2 September 1848, the Viennese revolutionary publication Wiener Katzenmusik published an article titled "Communism, Socialism and Humanism" that argued for humanism and a new, more humane organization of society (neue menschliche Ordnung der Gesellschaft) ${ }^{84}$

Thus, in revolutionary publicity, following the collapse of censorship in countries like Prussia and Austria, the concept of humanism was often intertwined with early socialist terminology and democratic ideas, which had come to German-speaking countries from abroad, mostly from France. ${ }^{85}$ Karl Marx had published, with Friedrich Engels, the Manifesto of the Communist Party in February 1848, right before the outbreak of the German revolutions.

As the revolutions proceeded, emotions related to humanism shifted from optimism to disappointment. In the autumn of 1848, disappointed and pessimistic voices began to surface in the public sphere. For example, on 20 August 1848, five months after the outbreak of the Märzrevolution, and less than four months before the crowning of Franz Joseph as the new emperor of the Habsburg Empire, the pseudonymous D. S. K. wrote in an article published in the Sonntagsblätter titled "Humanism and Politics" that the revolution was doomed to fail and lead back to absolutism because it had abandoned the ideals of humanism and humanity: "We only changed the

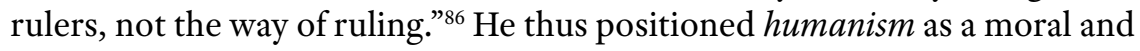
political ideal that remained unachievable as the revolution fell back into old forms of oppression and violence.

The intimate and problematic linkage between humanism, violence, and moral issues during and after the revolution can also be seen in another issue that was covered in the press. In 1848-49, humanism was discussed on several occasions in debates on corporal punishment and death penalty ignited

83. "Sonst war die Freiheit Nationalismus, jetzt ist sie Humanismus." Ferdinand Kürnberger, "Die Freiheit und das 19. Jahrhundert," Sonntagsblätter, 25 June 1848. See also "Die Tonkünstler-Versammlung zu Leipzig," Neue Zeitschrift für Musik, 5 September 1848.

84. "Kommunismus, Socialismus und Humanismus," Wiener Katzenmusik, 2 September 1848 .

85. See further Bödeker, "Menschheit," 1124-1126; Evans, “Liberalism, Nationalism,” 17.

86. "Wir haben nur die Machthaber gewechselt, nicht aber die Art die Macht zu haben.” D. S. K., “Der Humanismus und die Politik,” Sonntagsblätter, 20 August 1848. 
after the Frankfurt Parliament abolished it in 1848: "Thus it is altogether irreconcilable with the humanism of our century to chastise men until they bleed, while we at the same time form associations for the protection of animals, and make their protection an affair of public morality." "The death penalty, so they say, dates back to the dark ages of violence, and cannot exist in the age of humanism." 88

Already in the first decades of the nineteenth century, inspired by the Declaration of the Rights of Man and of the Citizen and the Enlightenment, prison sentences became increasingly preferred over corporal punishments. Furthermore, as judicial officials and legal specialists discussed the death penalty in the states of the German Confederation between 1815 and 1848, and especially in the 1840s, they favored concepts like humanity and civilization over old religious arguments. ${ }^{89}$ In the press, as well, humanism reflected this new, secular understanding of justice and human rights. ${ }^{90}$ Accordingly, during the collapse of the old regimes, humanism was marked by an ongoing effort to redefine the fundamentals of human existence and social order by delineating a new moral system that was increasingly independent from God.

\section{After the Revolution}

The radical secular interpretations of humanism around 1848 led to a strong reaction after the revolution. Once absolutist power and censorship were restored, humanism began to appear in a negative light in the source corpus, criticized in articles from religious or diocesan publications. For example, an article titled "Humanismus und Revolution" published in the Wiener Kirchenzeitung in 1858 warned against falsely appealing to classical authors for arguments supporting social radicalization: "to use the study of the classics as a battering ram against divine revelation and Christian conviction, and thus

87. "So ist es überhaupt mit dem Humanismus unseres Jahrhunderts im höchsten Grade unverträglich, einen Menschen bis zum Blutvergießen zu züchtigen, während wir zum Schutze der Thiere Vereine stiften, und ihre Schonung zu einem Gegenstande der öffentlichen Moral machen.” Wiener Abendzeitung, 22 May 1848.

88. "Die Todesstrafe stamme aus den finsteren Zeiten der Gewalt, und könne in der Zeit des Humanismus kein Bestehen haben." "Reichstags-Verhandlungen," Wiener Zeitung, 26 January 1849. See also Miscelle, "Die Todesstrafe," Der Österreichische Zuschauer, 9 September 1848. "Reichstags-Verhandlungen," Wiener Zeitung, 31 January 1849.

89. Richard J. Evans, Rituals of Retribution: Capital Punishment in Germany 1600-1987 (Oxford: Oxford University Press, 1996), 240-284.

90. E.g., "Kremster 24. Jänner," Die Presse, 27 January 1849; “Körperliche Strafen,” Wiener Abendzeitung, 22 May 1848. "Oesterreich und Deutschland," Innsbrucker Zeitung, 6 February 1849. 
to prepare the youth for social revolution, this endeavor can be described with full historical justification by one specific word: humanism." ${ }^{\prime 1}$

Moreover, research has identified the era after the revolutions as a time when the meaning of humanism became stabilized. After the 1850s, humanism was increasingly understood as a periodizing term that referred to the Renaissance era. ${ }^{92}$ Yet it seems that the political connotations of humanism did not entirely disappear, but persisted in late nineteenth-century public discourse. The 1848/49 revolutions affected the ways in which humanism was conceived and evaluated in the late nineteenth century in Germanophone and non-Germanophone public discourse alike. ${ }^{93}$ For instance, Jonas Hanssen elucidates how the concept of humanism appeared as a radical concept in Sweden before 1848, but was increasingly transformed into a conservative, periodizing term in the second half of the nineteenth century. ${ }^{94}$ The political interpretation of humanism also resonated in the Finnish public sphere in the second half of the nineteenth century, and humanism was often juxtaposed with religion. ${ }^{95}$

The secularization of humanism also had vast implications for AngloAmerican intellectual history, the interpretation of it as a non-theistic "approach to life" won out. ${ }^{96}$ Today's humanist associations often depict them-

91. "das Studium der Klassiker als einen Sturmbock gegen göttliche Offenbarung und christliche Gesinnung zu benützen, und somit die Jugend für die soziale Revolution vorzubereiten, dieses Bestreben kann ganz mit historischem Recht, mit dem spezifischen Wort: Humanismus bezeichnet werden." "Humanismus und Revolution," Wiener Kirchenzeitung, 6 October 1858.

92. Humanism began to be used as a concept to refer to a period by L. G. Voigt, Die Wiederbelebung des classischen Alterthums oder das erste Jahrhundert des Humanismus [The revival of classical antiquity or the first century of humanism] (Berlin: Georg Reimer 1859). See Bödeker, "Menschheit, Humanismus, Humanität," 1126; Bommel, Classical Humanism, 24; Cancic, "Humanismus," 9.

93. On the political connotations of humanism in the twentieth century, see Matthias Löwe and Gregor Streim, eds., "Humanismus" in der Krise: Debatten und Diskurse zwischen Weimarer Republik und geteiltem Deutschland ["Humanism" in crisis: Debates and discourses between the Weimar Republic and divided Germany] (Berlin: Walter de Gruyter, 2017); Horst Groschopp, Der ganze Mensch: Die DDR und der Humanismus. Ein Beitrag zur deutschen Kulturgeschichte [The whole person: The GDR and humanism. A contribution to German cultural history] (Marburg: Tectum Wissenschaftsverlag, 2013).

94. Jonas Hansson, Humanismens kris: Bildningsideal och kulturkritik i Sverige 18481933 [The crisis of humanism: Educational ideal and cultural criticism in Sweden 18481933] (Stockholm: Brutus Östlings Bokförelag Symposion, 1999), 77-106.

95. Aleksi Vesanto, Filip Ginter, Hannu Salmi, Asko Nivala, Reetta Sippola, Heli Rantala, and Petri Paju, "Text Reuse in Finnish Newspapers and Journals, 1771-1910," http://comhis.fi/clusters, (accessed 31 January 2018).

96. Andrew Copson, "What is Humanism?," in The Wiley Blackwell Handbook on Hu- 
selves as non-religious, socially oriented movements. ${ }^{97}$ The understanding of humanism that came to life in German-speaking countries in the 1840s thus influenced later interpretations of humanism, establishing it as a modern emancipatory and secular concept.

\section{Conclusion}

This article sought to analyze how the concept of humanism emerged in various popular texts within the German states from the Vormärz era to the aftermath of the 1848-49 revolutions. Instead of tracing the meanings of $h u$ manism back to the thoughts and writings of individuals, I focused on the role of textual networks in the transfer of ideas, meanings, and emotions from one context to another. Although individuals such as Friedrich Immanuel Niethammer and Arnold Ruge played a major role in the intellectual history of nineteenth-century humanism, the discursive practices and networks of the early nineteenth-century press significantly contributed to the conceptual architecture that established humanism as a concept that migrated from pedagogical debates into the political language of the 1840s.

The study of newspaper databases supports existing understandings of the emergence of political interpretations of humanism in the 1840s, as discussed in the Geschichtliche Grundbegriffe, but it also gives new insights into how humanism was adapted to political language before and during the 1848-49 revolutions. Because the press played a major role in the emancipation of the Bürgertum and in mobilizing the revolutions, it was deeply involved in the process of politicizing human-centered concepts like humanity and humanism and constructing the latter as a cosmopolitan, emancipatory, future-oriented ism.

The construction of this ism was also emotional: newspapers played upon the emotional connotations of human-centered concepts, such as solidarity, compassion, and Menschenliebe, and thereby transformed these emotions into a political force. Newspapers and periodicals linked human inequality to human suffering and referred to humanism as a position that might ameliorate these problems. The diversity of contemporaneous political and social contexts in which newspapers referred to the concept give reason to believe that in the 1840s, humanism gained not only a new

manism, ed. Andrew Copson and A. C. Crayling (Sussex: Wiley Blackwell, 2016), 1-34, here 2 .

97. See, e.g., American Humanist Association, https://americanhumanist.org/about/ (accessed 26 March 2018); Humanist UK, https://humanism.org.uk/about/ (accessed 26 March 2018). 
political orientation but also a mutable emotional charge that affected its internal structure and its associations with other concepts in the early nineteenth-century press. Grasping these political connotations and emotional underpinnings helps us understand why humanism became culturally contagious before and during the $1848-49$ revolutions.

Heidi Hakkarainen is a postdoctoral researcher at the Department of Cultural History at the University of Turku. Email:heidi.hakkarainen@utu.fi 